\title{
Metagoverning Collaborative Innovation in Governance Networks
}

Sørensen, Eva; Torfing, Jacob

Published in:

American Review of Public Administration

DOI:

10.1177/0275074016643181

Publication date:

2017

Document Version

Peer reviewed version

Citation for published version (APA):

Sørensen, E., \& Torfing, J. (2017). Metagoverning Collaborative Innovation in Governance Networks. American Review of Public Administration, 47(7), 826-839. https://doi.org/10.1177/0275074016643181

\section{General rights}

Copyright and moral rights for the publications made accessible in the public portal are retained by the authors and/or other copyright owners and it is a condition of accessing publications that users recognise and abide by the legal requirements associated with these rights.

- Users may download and print one copy of any publication from the public portal for the purpose of private study or research.

- You may not further distribute the material or use it for any profit-making activity or commercial gain.

- You may freely distribute the URL identifying the publication in the public portal.

Take down policy

If you believe that this document breaches copyright please contact rucforsk@kb.dk providing details, and we will remove access to the work immediately and investigate your claim. 


\title{
Metagoverning Collaborative Innovation in Governance Networks
}

\author{
Eva Sørensen and Jacob Torfing
}

American Review of Public Administration, draft version, Accepted for publication

Keywords:

Governance, networks, public innovation, metagovernance, public administration

\begin{abstract}
Western liberal governments increasingly seek to improve the performance of the public sector by spurring innovation. New Public Management reforms from the 1980s onwards viewed strategic entrepreneurial leadership and public-private competition as key drivers of public innovation. By contrast, the current wave of New Public Governance reforms perceives collaboration between relevant and affected actors from the public and private sector as the primary vehicle of public innovation, and tends to see governance networks as potential arenas for collaborative innovation. The new focus on collaborative innovation in networks poses a fundamental challenge for public managers, elected politicians and others aiming to metagovern governance networks. Hence, we claim that a specific metagovernance strategy is needed when the purpose of governance networks is to stimulate efficiency, effectiveness and democratic legitimacy through innovation rather than incremental improvements. The article aims to sketch out the contours of such a strategy by comparing it with more traditional metagovernance strategies. The argument is
\end{abstract}


illustrated by an empirical analysis of an example of collaborative innovation in Danish elderly care.

\section{Metagoverning Collaborative Innovation in Governance Networks}

\section{Introduction}

Western liberal governments have become increasingly interested in promoting public innovation in response to fiscal constraints (Pollitt, 2010), the proliferation of wicked and unruly problems (Koppenjan and Klijn, 2004; Roberts, 2000), the citizens' growing distrust of democratically elected governments (Macmillan and Cain, 2010; Levin et al, 2012; Norris, 2011), and the socioeconomic challenges associated with globalization (OECD, 2015). In the past, innovation was only considered relevant for the private sector, and public innovation policies focused exclusively on how the public sector could create favorable conditions for growth-enhancing innovation in private businesses. Public innovation was perceived as impossible due to inherent institutional rigidities in the public sector and lack of market-based competition (Downs, 1975). Those days are over. Today, public authorities increasingly view public innovation as a tool for improving public governance and strategic efforts are made to enhance the capacity of the public sector to formulate, implement and diffuse innovative public policies, services, organizational designs and procedures.

Initial efforts to make the public sector more innovative drew on traditional private sector innovation theories (Schumpeter, 1946), which regarded strategic entrepreneurial 
leadership and market-based competition as the main drivers of innovation (Osborne and Gaebler, 1993). However, a new strand of public sector innovation theory draws on central insights from recently developed private sector innovation theories that emphasize the importance of strategic alliances and public-private innovation systems (Lundvall, 1985; Freeman, 1991; Teece, 1992). These insights are combined with fresh ideas from theories of collaborative governance that underscore the role of mutual exchange and learning (Ansell and Gash, 2008; Osborne, 2010; Bommert, 2010; Sørensen and Torfing, 2011). As a result, the new approach highlights the role that multi-actor collaboration can play in enhancing public innovation. Moreover, it views governance networks as institutional frameworks for promoting collaborative innovation in the public sector (Dente, Bobbio and Spada, 2005; Eggers and Singh, 2009; Bland et al., 2010; Considine, Lewis and Alexander, 2009). At the same time, it cautions that the success of governance networks in promoting collaborative innovation depends on the degree to which networks are skillully metagoverned in the sense of being steered and managed in ways that influence their processes and outcomes without reverting too much to traditional forms of command and control (Jessop, 1998; Kooiman, 2003; Koppenjan and Klijn, 2004; Sørensen and Torfing, 2007).

There is considerable knowledge about how governance networks can increase the efficiency and effectiveness of public regulation and service production through the enhancement of resource exchange and pluricentric coordination and how they can enhance the democratic legitimacy of public governance by facilitating participation in ongoing public decision-making processes. There is also a good deal of knowledge about how metagovernance defined as the 'governance of governance' (Kooiman, 1993) can enhance the impact of governance networks on efficiency, effectiveness and democratic 
legitimacy. What we lack, however, is an understanding of how governance networks can be metagoverned in order to spur the development of innovative policies, services, organizations and processes that in turn may help to boost efficiency, effectiveness and democratic legitimacy of public governance. Our claim is that a specific metagovernance strategy is needed when the purpose of networking is to improve public performance through disruptive innovations rather than incremental improvements of existing practices. The article aims to identify the distinctive features of such a strategy through a comparison with more traditional metagovernance strategies. As such, it provides much needed knowledge about how metagovernors can stimulate collaborative innovation in governance networks in order to achieve desirable performance outcomes.

The article begins by describing four factors believed to have motivated contemporary Western governments to pursue public innovation. It then discusses how collaboration can contribute to the development and diffusion of public innovation. After having described how governance networks can serve as arenas for collaborative innovation, it argues that their innovative capacity depends on how they are metagoverned, and compares a distinct metagovernance strategy for promoting collaborative innovation in governance networks with more traditional metagovernance strategies that aim to enhance efficient, effective and democratic governance through continuous improvement. An empirical example of metagoverned collaborative innovation in Danish elderly care is then analyzed. Finally, the conclusion summarizes the argument and points to some further avenues of research.

\section{The rise of the public innovation agenda}


The current efforts of public officials to stimulate public innovation challenge our thinking about governance networks and how they are metagoverned. We shall, therefore, briefly consider four factors that contribute to explaining why public innovation has become a core concern for Western governments and is likely to remain so in the foreseeable future.

The first factor is the economic crisis and its dire fiscal consequences for public spending. As pointed out by Christopher Pollitt (2010), public innovation is an attractive alternative to both brutal, strategic spending cuts that may hamper the responsible politicians' chances for re-election and blind across-the-board cuts that lead to increased stress among public employees and poorer public services. By contrast, the public innovation agenda suggests that innovation may enable governments to provide more and better public services at lower or equivalent costs.

The second factor is the proliferation of wicked and unruly problems. Public authorities are facing a growing number of problems such as homelessness, integration of immigrants and refugees, climate change, gang-related crime, etc. that are hard to crack due to a complex mixture of cognitive and political constraints (Rittel and Webber, 1973; Levin et al., 2012). Complex problems can neither be solved by standard solutions nor by increased public spending, but call for innovative solutions that can break the trade-offs between conflicting goals and externalities that often result in political stalemate and policy deadlocks.

The third factor is the citizens' growing distrust of elected politicians and their general disenchantment with representative democracy (Dalton, 2004; Stoker, 2006; Norris, 2011). Spurred by the educational revolution and the anti-authoritarian revolt in the 1960 s citizens in advanced liberal democracies tend to demand a more active participation in and direct 
influence on public decisions that affect their daily lives than accommodated by traditional institutions of liberal representative democracy. As a result, we are witnessing a proliferation of democratic innovations that aim to give citizens a more active and direct role in governing society (Fung, 2006; Smith, 2009; Warren, 2009; Agger and Sørensen, 2014).

The final factor is the competitive pressures from China, India, Brazil and other growth economies that are fuelled by the ongoing globalization of world markets. In order to secure the systemic competiveness of their national economy and public welfare systems, Western governments are forced to improve the functioning of the educational system, the labour market, regulatory institutions and technological infrastructures (Porter, 1990; Cerny, 1997; EU-Commission, 2013). Given the intensity of the pressures and the urgency of reforms, incremental changes must give way to disruptive innovations.

These four factors explain the growing interest in public innovation among politicians, public managers, policy experts and mass media. Exactly how government officials in different countries and at different levels will respond to these different innovation pressures is far from certain and depends on how these pressures are experienced and interpreted, as well as on the political and institutional culture and capacity of government. Nevertheless, the general situation is that public innovation is currently high on the public sector agenda.

\section{Collaboration as a driver of public innovation}

Public innovation can be defined as a more or less intentional effort to design, realize and diffuse new public policies, services, organizations and procedures that disrupt established 
practices and conventional thinking in a particular domain (Torfing, forthcoming). As argued by Everett Rogers (1995) and Jean Hartley (2005), the fact that an innovation signifies newness does not necessarily mean that it represents an entirely novel invention. Many innovations are borrowed from elsewhere or result from the recombination of old elements, perhaps with the addition of some new ones. For something to count as an innovation, it only needs to be new in the context in which it is implemented (Roberts and King, 1996). Whether something is considered as new by situated actors depends on whether it disrupts existing practices and ways of thinking. An innovation, however, involves a more or less radical step-change rather than a continuous improvement of existing practices (Hartley, 2005).

It should also be emphasized that innovation does not always lead to improvement (Hartley, 2005). Many innovations go wrong, or fail to deliver the intended results, and even if the result is praised by the innovator(s), other actors may not like it. How an innovation is evaluated depends on the eyes of the beholder. Different actors may arrive at different conclusions regarding whether an innovation is an improvement or a setback.

Finally, it should be noted that innovation is both a creative and a destructive activity (Schumpeter, 1946). Innovations always come at a cost, and the evaluation of what is gained through innovation must always be measured against what is lost. The mixed impact of innovation is important because public innovation tends to affect all members of society and not only a group of customers who can choose another supplier if they are dissatisfied.

The fact that innovation can both result in gains and losses for the entire population might explain why public actors are often reluctant and cautious in the pursuit of public 
innovation. Innovation failures and unanticipated negative effects can wreck political and administrative careers and generate media storms and citizens' protests. The pressures to innovate seem to leave Western governments with little alternative, however, but to consider how the public sector can become more innovative.

There have been different ideas about how the public sector should pursue innovation. The New Public Management (NPM) reform program found inspiration in traditional theories of private sector innovation (Schumpeter, 1946), which valued the entrepreneurial spirit of great inventors and courageous business leaders and regarded inter-firm competition as the main driver of innovation. The NPM reform program took these initial ideas one step further by arguing that strategic management in the public sector and competition between public and private service providers would create a more innovative public sector (Hood, 1991; Osborne and Gaebler, 1993).

While still recognizing that entrepreneurialism and competition are important innovation drivers, the more recent ideas associated with the emerging New Public Governance (NPG) reform program (Osborne, 2010) suggest that collaboration is a superior driver of public innovation. While strategic leadership is indispensable for putting innovation on the agenda and allocating time and resources to the pursuit of innovation, and competition provides public actors with a strong motivation to innovate, collaboration is what actually produces innovations by stimulating mutual and transformative learning and generating support for the realization of new disruptive ideas (Roberts, 2000). Public innovation is a team sport rather than the work of lone wolves.

The NPG reform program takes its inspiration from recent theories of private sector innovation (Lundvall, 1985; Freeman, 1991;Teece, 1992; Edquist, 2005) as well as from 
the new theories of collaborative governance (Hartley, 2005; Ansell and Gash, 2008; Torfing et al., 2012). The core argument derived from these theories is that collaboration between relevant and affected actors from the public, non-profit and for-profit sectors can support and strengthen each of the constitutive phases in the innovation process (Hartley, Sørensen and Torfing, 2013; Ansell and Torfing, 2014). An informed dialogue among actors with different kinds of knowledge and experience may help to develop a deeper understanding of a problem; deliberation can bring forth, critically scrutinize, qualify and integrate new and creative ideas; joint design, testing and assessment of prototypes is a promising way of selecting and adapting the most promising solutions; the development of joint ownership over new and bold solutions enhances the prospect of successful implementation; and widespread participation in the design of innovative solutions is a valuable mechanism for recruiting ambassadors willing and committed to diffusing innovative solutions to others (Eggers and Singh, 2009).

Collaboration stimulates innovation by harnessing rather than eliminating difference (Gray, 1989). Exchanges among actors with different experiences, perspectives, opinions, ideas and resources tend to challenge conventional wisdom and inspire the creation of something new. Whether or not collaboration leads to innovation depends on: 1) the actors' perception of the urgency of the problem or challenge at hand; 2) how much they trust each other and how well they communicate and deal with emerging conflicts; 3) whether past experiences, existing interdependencies and the incentive structure allow them to reach some sort of rough consensus or shared agreement; and 4) the extent to which there are institutional procedures for sharing the costs and risks associated with innovation (Brown and Osborne, 2013). However, even when a collaborative process is unsuccessful or fails to enhance innovation, the interaction among the actors may produce 
spin offs in terms of social capital, new understandings oft problems, and creative ideas that may lead to innovations later on, or in different contexts.

\section{Governance networks as arenas for collaborative policy innovation}

The myth of a dynamic and innovative private sector and an ossified and change resistant public sector is dispelled by the many spectacular examples of public innovations such as the introduction of active employment policy, recycling of garbage, one-stop shops, on-line education and tele-medicine. Even in the technical field, the invention of the internet, GPS and drones bears witness to the innovativeness of the public sector (Mazzucato, 2013). Unfortunately, public innovation tends to be episodic and accidental and thus fails to enhance the future capacity for innovation (Eggers and Singh, 2009). One way of turning public innovation into a more permanent and systematic endeavor is to institutionalize arenas where collaborative innovation can take place. A burgeoning literature points to the formation of governance networks as a way of facilitating and spurring collaboration between relevant and affected actors from the public, for-profit and non-profit sectors (Scharpf, 1994; Kickert, Klijn and Koppenjan, 1997; Agranoff and McGuire, 2003). A governance network may be defined as a horizontal institutionalization of the interaction of interdependent but operationally autonomous actors who collaborate in a shared effort to define and create public value through a process of regulated self-regulation (Sørensen and Torfing, 2007). The specific strength of governance networks compared to other institutional forms of governance, such as hierarchies and markets, is that they aim to mobilize and exploit the self-governing capacity of public and private stakeholders within boundaries defined, more often than not, by government actors. Hence, governments can 
share the governing responsibility with external actors who can bring new ideas, competences and resources to the table.

Governance theorists agree, however, that governance networks are not always successful in contributing to public value production, either because they fail to include the relevant and affected actors; because the tasks and goals are too vague or ill-defined; because cultural differences or conflicts of interest prevent resource exchange; or because there is a misalignment between the strategy pursued by the network and the overall strategy of government. Research demonstrates that there is a tendency towards homophily in networks that is not conducive to the broad inclusion of relevant and affected actors (McPherson, Smith-Lovin and Cook, 2001). Other studies shows that network collaboration is sometimes hampered by internal conflicts, low levels of trust and an inability to communicate constructively about ends and means (Faerman, McCaffery and Slyke, 2001). Governance networks may also sometimes pursue dark and illegitimate agendas and strategies, or formulate skewed interpretations of public value that conceal the real pursuit of private interests (Marsh and Rhodes, 1992; Milward and Raab, 2007).

In recognition of the possibility of governance network failure governance researchers have developed the term 'metagovernance' to describe the ways in which public authorities and other central, capable and legitimate actors can govern governance networks without reverting too much to traditional forms of command and control (Sørensen and Torfing, 2009). As such, metagovernance refers to a specific kind of second- and third-order governance that aims to improve the functioning and capacity of relatively self-governing networks to produce governance solutions that enhance the production of public value (Jessop, 2002; Kooiman, 2003; Torfing et al., 2012). The concept of 'metagovernance' shares its concern for how to influence the performance of 
networks with the concept of 'network management' that has been developed by both European (Kickert, Klijn and Koppenjan, 1997; Theisman, Burren and Gerrits, 2009) and North American scholars (Agranoff and McGuire, 2003; Milward, and Provan, 2006; Provan and Kenis, 2008). However, whereas the network management literature is primarily interested in how public managers can get things done by creating wellfunctioning networks, the metagovernance literature combines the focus on network management with a broader political steering perspective concerned with the question of when and how networks can contribute to interest-mediation and the achievement of overall political goals (Peters, 2010; Sørensen and Torfing, forthcoming).

The challenge for public metagovernors such as elected politicians, public managers, or other actors with a delegated authority is to influence the network, while recognizing that it needs a certain degree of autonomy in order to define its purpose and objectives, its modus operandi, and the outputs and outcomes it aims to produce. Without this autonomy, the participating actors will tend to lose their incentive and motivation to participate in joint problem solving. Governance theorists list a number of ways in which public authorities can metagovern governance networks. The tools of metagovernance can be divided into four main categories: 1) political, discursive and financial framing that aims to define the basic task of the network and the conditions for solving it by defining the overall objectives, crafting a particular narrative, or encouraging governance networks to pursue particular strategies through the allocation of financial resources and other privileges; 2) institutional design that aims to create formal or informal arenas for interaction between a particular group of actors and define the basic rules of engagement; 3) network facilitation that aims to support and nurture a constructive management of difference through different kinds of process management by lowering the transaction costs of interacting, mediating conflicts 
and supporting mutual learning processes; and 4) network participation that aims to influence the joint production of outputs and outcomes by aligning the goals of the actors and defining decision making criteria.

These four metagovernance tools should be viewed as complementary rather than as mutually exclusive. Hands-off forms of metagovernance via framing and design of networks can benefit from hands-on metagovernance through facilitation of and participation in networks. By the same token, hands-on forms of metagovernance rarely function well if they are not underpinned by hands-off forms of governance. The metagovernance of governance networks is a complex and difficult endeavor which can easily go awry. The key challenge for metagovernors is to avoid regulating the governance networks too much or too little (Sørensen and Torfing, 2009). If, on the one hand, governance networks are metagoverned too tightly, the network actors lose their motivation to participate in self-regulated interaction. On the other hand, too little or too weak metagovernance can result in a destructive discrepancy between the strategy pursued by the governance network and the goals pursued by public authorities. Whether or not governance networks become a positive governance tool depends, to a large extent, on whether metagovernors find the right level of interference in the governance network. It also depends, as we will argue, on whether the chosen metagovernance strategy fits the purpose assigned to the governance network.

Before elaborating on how the choice of metagovernance strategy is contingent upon the purpose of the governance network, it is important to explain what it takes to become a successful metagovernor. A metagovernor is an actor, or group of actors, that aims to initiate, support and guide collaboration in governance networks in order to ensure that they contribute to the production of public value (Sørensen and Torfing, 2007). It is not the 
prerogative of the public authorities to step into the role of metagovernor. Private actors, such as community leaders, interest organizations and business leaders, might seek to take on this position and their success in doing so depends, among other things, on whether they possess the centrality, resources and ability to do so. Hence, the ability of a given actor to metagovern governance networks relies on its access to what Christopher Hood defines as 'NATO' resources' (Hood, 1986). 'N' stands for nodality and points to the importance of being a centrally located actor that possesses a web of contacts and connections to relevant stakeholders within a given governance area; ' $A$ ' refers to authority and refers either to formal decision making power, or an informal position as an actor that other actors respect and listen to; ' $T$ ' is treasure, and denotes access to funding which makes it possible to grease the wheels and pay the bills of joint action; and ' $O$ ' points to organizational capacity to reflect upon and support the network process. While private actors sometimes possess one or more of these resources, public actors are part of a political and administrative system that endows them with all of these resources. That said, we often see that successful metagovernance is exercised by a team of public and private actors. Hence, although public actors tend to possess most or all of the NATO resources, private actors have the advantage of being able to elude some of the red tape that often hampers public authorities in their efforts to metagovern governance networks. To further complicate things, there might be competing metagovernors placed at different levels. As such, metagovernance may be contradictory and prone to failure.

\section{Metagoverning governance networks with differing purposes}


Students of governance networks have, first and foremost, focused on how governance networks can contribute to enhancing the efficiency and effectiveness of public governance by facilitating resource exchange and pluricentric coordination that creates synergy, prevents overlaps, eliminates gaps and enhances flexibility (Kooiman, 1993; Koppenjan and Klijn, 2004). More recently, however, there has been a growing interest in how governance networks can increase democratic legitimacy by enhancing democratic participation and deliberation (Klijn and Skelcher, 2007; Skelcher and Torfing, 2010; Sørensen and Torfing, 2009). The basic assumption has been that the formation of governance networks will improve efficiency and effectiveness through an adjustment of public policies and services to the needs and demands of relevant actors and enhance democratic legitimacy through the provision of a supplementary channel for participation of intensely affected actors. Although there has been some interest in 'policy learning' (Sabatier and Jenkins-Smith, 1993) and 'complex problem-solving' (Koppenjan and Klijn, 2004), innovation has seldom been an explicit part of the equation (for an exception see O'Toole, 1997). However, governance networks aiming to enhance efficiency, effectiveness and democratic legitimacy may benefit from a systematic pursuit of innovation (Dente, Bobbio and Spada, 2005; Glor, 2005; Eggers and Singh, 2009; Considine, Lewis and Alexander, 2010). Collaborative policy and service innovation can help to cut costs while enhancing the capacity to solve wicked and unruly problems, and creative design of new democratic institutions and procedures can improve the democratic performance of the public sector. Hence, as indicated in Figure 1 below, governance networks can achieve key performance goals either directly though incremental improvement or indirectly through the pursuit of innovation.

Figure 1: Causal links between governance networks and key performance goals 
[Please insert Figure 1 here]

Figure 1 clearly indicates that innovation is not a goal in itself, but rather a means to an end. However, the unfortunate neglect of innovation in the discussion of the role and impact of governance networks has significant consequences for the research on metagovernance. Whereas there has been considerable focus on how to metagovern governance networks in the pursuit of efficiency, effectiveness and democratic legitimacy through incremental changes facilitated by collaborative interaction (Sørensen and Torfing, 2009), there has so far been no attempt to think through how metagovernance can help to stimulate collaborative innovation as a tool for enhancing efficiency, effectiveness and democratic legitimacy through networking.

In order to address this neglected area, we propose that metagovernance strategies that seek to stimulate innovation will differ substantially from the well-known metagovernance strategies aimed at enhancing either efficiency and effectiveness or democratic legitimacy through continuous improvement.

Below, we sketch out the contour a metagovernance strategy aimed at promoting public innovation through networked collaboration. In order to be able to see how it differs from other metagovernance strategies we compare it with the metagovernance strategies for continuous improvement of efficiency and effectiveness and democratic legitimacy. The three metagovernance strategies are compared on the basis of three important strategic questions: 1) Which actors should be included in the governance network? 2) What should the network actors be encouraged to do in the network arena? 3) What kind of impact should the network as a whole have on its external political and/or administrative 
environment? The different answers to these three basic questions are displayed in Table 1.

Table 1: $\quad$ Comparison of three metagovernance strategies

[Please insert Table 1 here]

In the next three sections we take a closer look at the different answers to each of the three strategic questions in order to identify the distinctive features of the metagovernance strategy for enhancing collaborative innovation in governance networks. In so doing we draw on the account of different metagovernance tools from the previous section.

\section{Which actors should be included in the governance network?}

Metagovernors can affect the composition of governance networks by using different metagovernance tools. However, as indicated in Table 1, metagovernors' decision about the composition of a governance network must be informed by a clear understanding of the overall purpose of the governance network.

If the goal is to enhance the efficiency and effectiveness of public governance by facilitating resource exchange, crosscutting coordination and a flexible adaptation of joint solutions to shifting conditions, a key task for metagovernors is to promote the inclusion of actors with relevant resources, competencies and forms of knowledge who can help to make better use of the existing resources and ensure that the solutions meet the needs and demands of relevant stakeholders. If the public governance system lacks the 
resources, skills and capacities to improve system performance, the metagovernors may try to include private actors who have something to offer. If a local government aiming to secure sustainable water management is prevented from achieving this by inflexible regional or national regulations, public metagovernors may try to broaden the participation in local water management network to include regional and national authorities. Finally, efforts should be made to ensure that the included actors are committed to achieving the overall goal of the network and willing to manage their differences in the pursuit of this goal. Hence, actors that could potentially obstruct the joint attempt to craft efficient and effective solutions should only be included in the network if their negative influence can be contained and their inclusion will help to give them a sense of joint ownership over the solutions crafted by the governance network. If these conditions are not fulfilled, the potential veto actors should be excluded. However, there is also a risk that the governance network will become too exclusive. Hence, when thinking about which actors to include and exclude metagovernors can easily fall into the trap of only inviting those actors with whom they are well acquainted and feel comfortable because they share core values and speak the same language (McPherson, Smith-Lovin and Cook, 2001; Sørensen and Torfing, 2009). Rounding up the usual suspects will most likely lead to the exclusion of actors with resources, competencies and forms of knowledge that are critical to the development of appropriate, low cost solutions to the problem and to achievement of the stated objectives. In short, metagovernors who aim to achieve more efficient and effective governance through the exchange and pooling of resources should compose a committed team of network actors who, each in their own way, can contribute to achieve the overall goal and together have all the necessary resources, competences and forms of knowledge. 
Metagovernors who are primarily interested in enhancing democratic legitimacy would opt for a rather different composition of governance networks based on an alternative set of criteria. Democracy is basically about giving those constituencies who are intensely affected by, or interested in, specific governance decisions an opportunity to influence those decisions (Dahl, 1989) and to secure that all relevant discursively constructed arguments are heard and taken into account in the decision-making process (Dryzek, 2007). In representative democracies, these objectives have mainly been realized through free and equal citizen participation in general elections. However, the declining trust in elected politicians in Western liberal democracies has triggered a search for supplementary forms of participatory democracy that enhance and improve the dialogue between politicians and citizens and grant the latter a more direct and substantive influence on public governance (Hirst, 2000; Dalton, 2004; Fung, 2006, Norris, 2011). The creation of user boards, experimentation with participatory budgeting, and the establishment of advisory mini-publics are cases in point, as is the formation of governance networks that bring together politicians, for- and non-profit organizations and empowered citizens in more or less institutionalized policy-making arenas (Agger and Sørensen, 2014). Whether or not governance networks end up enhancing democratic legitimacy depends on the extent to which they include a broad set of public and private actors who together represent the views and opinions of relevant and affected constituencies and different kinds of political discourse that have a bearing on the issues dealt with in the governance network. For instance, a governance network formed around a concrete public transport project should include existing and potential passengers as well as those affected by emerging negative externalities and it should include organizations in favour of sustainable transport systems as well as organizations 
representing car owners. However, a broad and representative inclusion is not enough. Hence, it is important to ensure that the actors included in the governance network are empowered to influence the decisions that affect their lives and values. Far too often formal inclusion of disempowered actors results in an internal exclusion of these actors (Young, 2000). It is, therefore, important to empower the network actors by endowing them with relevant knowledge, rights and resources and developing their political capacities and democratic identities (March and Olsen, 1995). A fundamental challenge is that public metagovernors tend to favor the inclusion of social and political actors who possess important resources such as fiscal means, expert knowledge, political authority and organizational capacities, and to overlook affected actors with fewer or no such resources. While this may be perfectly understandable if the purpose is to promote efficiency and effectiveness, it is problematic if the goal is to deepen democracy by involving citizens and private stakeholders in participatory and deliberative forms of democracy. In order for governance networks to serve a democratic purpose, they must be democratically anchored in all the affected constituencies and relevant discourses (Sørensen and Torfing, 2005) and public metagovernors should use a broad set of tools to ensure this anchoring (Sørensen and Torfing, 2009).

Metagovernors aiming to improve public performance by enhancing public innovation through collaboration in governance networks must strive for yet another type of network composition. Whereas continuous improvement of efficiency and effectiveness called for inclusion based on relevance and affectedness and the enhancement of democratic legitimacy urged metagovernors to ensure representative inclusion, the key task for metagovernors aiming to stimulate collaborative innovation is to ensure a creativityenhancing diversity. Collaborative innovation requires the inclusion of a diverse range of 
actors who possess important innovation assets such as first-hand experience with the problem or challenge at hand, expert knowledge about complex causalities, new and competing ideas, the capacity for creative thinking, the courage to experiment with new solutions despite the associated risks, competences and skills needed for implementation of new solutions, and tolerance towards complexity and cognitive dissonance in the consolidation phase. Diversity helps to prevent tunnel vision and enhance creative problem solving, while dense interaction over a long period of time helps to foster mutual trust and understanding, thus preventing destructive conflicts that might block the innovation process (Dente, Bobbio and Spada, 2005). Metagovernors have an important but also difficult job when it comes to ensuring diversity because there is a tendency to look askance at many of the above-mentioned innovation assets in public bureaucracies where predictability, regularity, stability, hierarchical order and control, and risk avoidance are core values (Bozeman, 2007). Governance networks that are dominated by norms and values from the public sector will tend to favor the inclusion of people who are professionally competent and represent important constituencies, rather than people capable of bringing about innovation through the creative destruction of existing ideas and practices. Metagovernors aiming to stimulate innovation must counteract this tendency to create homogenous networks of conformists by recruiting mavericks and people known to be unconventional (Roberts and King, 1996). However, the more heterogeneous an innovation network becomes, the greater is the task of the metagovernors to facilitate boundary spanning through the construction of trust-based interaction, translation of incommensurable vocabularies, and alignment of norms, values and interests (Williams, 2002). Since collaborative innovation may also be hindered by large discrepancies in the power resources held by highly diverse actors, encouraging the stronger actors to go-it- 
alone, metagovernors must create and strengthen relations of mutual dependency that can help to keep the network actors together and perhaps even persuade the stronger actors to give more room for the less powerful actors (Torfing, forthcoming).

\section{What should the network actors be encouraged to do?}

When the network actors are assembled the next task for metagovernors is to influence what they are doing and how they are interacting. Depending on the purpose of the networked interaction, the metagovernors must devise different metagovernance strategies that combine different metagovernance tools.

If the goal of the metagovernor is to facilitate interaction that makes public governance more efficient and effective, the network actors should be urged to exchange and pool their resources in a shared effort to solve the problem or task at hand in ways that ensure a flexible deployment of resources to reach the stated goals while at the same time adapting these goals to changing demands and circumstances. The first step is to assist the network actors in identifying important and relevant resources around the table, and then establish the interdependencies that may motivate those actors to share their different resources with each other and work together to produce satisfying outputs and outcomes at a relatively low cost. Independencies are not always evident to the network actors themselves, so an important task for metagovernors is to pinpoint what each of the involved actors can gain from working together (Kooiman, 1993). Sometimes, private forand non-profit contractors spend far too much time and energy competing with each other for public funding while overlooking the fact that they could save both time and money by working together to exchange resources and share facilities. The second step is to 
strategically change the network actors' perception of the field of action in order to enhance their propensity to collaborate, thereby paving the way for negative or positive coordination (Scharpf, 1994). While negative coordination aims to prevent a set of actors who are engaged in related activities from unwittingly harming each other, positive coordination encourages the network actors to formulate and pursue shared goals through joint initiatives and actions. To facilitate negative coordination, the task of the metagovernor is mainly to encourage continuous communication and motivate the network actors to share information and avoid stepping on each other's toes. Facilitating positive coordination is much more demanding since the network actors must be willing to align their objectives and act jointly to reach the common goals, while coping with emerging collective action problems such as free riding. The higher the level of coordination among the actors, the stronger the interdependencies must be, and metagovernors play an important role in shaping these interdependencies and promoting the coordination that is the key to efficient and effective governance.

The degree to which a governance network contributes to enhancing democratic legitimacy depends on, among other things, the extent to which the network actors are able to make joint decisions in accordance with aggregative and integrative democratic norms and values (March and Olsen, 1989), while securing the support of relevant constituencies, the general public and elected politicians (Sørensen and Torfing, 2005). In order to keep a network together and facilitate joint and democratic decision-making, there is a pressing need to find compromises that take into account, and seek to integrate, the different interests, views and arguments of the network actors. However, the final decisions should also reflect the relative weight of these different views and opinions in order to ensure that the preferences of the majority have a larger impact on the decisions 
than those of the minority. Moreover, it is important to ensure that decisions are made according to a democratic code of conduct, i.e. a set of agreed-upon rules and norms that ensures an even distribution of information, free and equal opportunities to be heard and to participate in joint deliberations, and transparency in the making of final decisions (Young, 2000). Sometimes, governance networks end up being undemocratic because a small group of network actors dominates and controls the entire network. Quite often, the problem is that the network actors did not negotiate and agree on a democratic network constitution at the outset. The dominant actors may have been selected and given a privileged role in the network because they can play an important role in achieving particular objectives, and the pursuit of these objectives may have overshadowed considerations about how to ensure democratic network governance. Nevertheless, metagovernors have an important role to play in establishing democratic procedures, norms and values and ensuring that they are upheld (Torfing, Sørensen and Fotel, 2009). Another crucial metagovernance task is to ensure that important decisions are endorsed by democratically elected politicians, that network participants actively seek the support of the constituencies they claim to represent, and that the network produces accessible and non-technical public accounts of its deliberations and actions in order to facilitate public scrutiny and accountability (Sørensen and Torfing, 2005). This is particularly important in governance networks where the participants are neither formally appointed nor democratically elected (Torfing et al., 2012), but rather self-selected and therefore cannot be trusted to defend the public good. In this case, metagovernors must not only work hard to infuse democratic norms and values into governance networks, but also to secure their democratic anchorage in a critical public sphere, the constituencies that are represented 
and the political decision-makers in the formal institutions of government ( Sørensen and Torfing, 2005).

If the purpose of the governance network is to advance public innovation as a way boosting public performance, the task of the metagovernors is neither to facilitate pluricentric coordination nor to promote democratic norms and secure democratic anchorage. The task is, rather, to engage network members in the destruction of existing beliefs and practices and the creative development, testing and implementation of new ones. In order to do so metagovernors must not only provide an initial definition of the problem at hand and convince the network actors of its urgency, but also promise to sponsor, steward and champion the creation of an innovative solution (Ansell and Gash, 2012). When the network actors have been motivated to engage in the development of an innovative solution, the metagovernor must ensure that they apply their different ideas, skills and competences. Differences in perspectives and mindsets among the network actors are important triggers of creative destruction and the creation of innovative solutions, but they can also produce tensions and conflicts that prevent deliberation, mutual learning and creative problem-solving. The first task of the metagovernor is, therefore, to create a positive trust-based atmosphere in the network that encourages the actors to speak their mind and question each other's perceptions and ideas in a constructive way without provoking destructive antagonisms. Heated debates between network actors with competing views can inspire the development of new and interesting problem definitions, creative policy solutions and cutting-edge public services, but if the actors begin to see each other as enemies the result will be growing unwillingness to listen to each other and to collaborate in finding innovative solutions to common and pressing problems. Metagovernors must also seek to catalyze transformative learning and out-of- 
the-box thinking by creating appropriate disturbances that bring the actors out of their comfort zones and encourage them to see problems and potential solutions from new angles, e.g. from the point of view of the users or target groups. Hence, a second task for metagovernors is to encourage critical reflection on existing paradigms and strategies and to provide perturbing inputs to the network through the circulation of new scientific results or the inclusion of actors with a completely different perspective or mind-set. Last but not least, metagovernors must help network actors to deal with the near-paralyzing uncertainty and risks associated with collaborative innovation. The precise effects of innovative solutions are uncertain and the risk of negative externalities may seem overwhelming to risk-averse public or private actors. Moreover, it is not always clear who is going to pay for the innovative solution and who will benefit, or perhaps lose, from its implementation. Hence, a third task for metagovernors is to reduce uncertainties and risks by encouraging fast learning through experimentation and the testing of prototypes and by initiating negotiations about the distribution of costs and benefits and the ways that losers may be compensated (Eggers and Singh, 2009; Bason, 2010; Torfing, forthcoming).

\section{What impact should the network have on its external environment?}

It is important for metagovernors to ensure that governance networks have a positive effect on their external environment. There is a tendency for network actors to look inwardly at the particular problem or task that they are facing and at their interests in and capacities for solving it. Although this emphatic focus on results is a major strength of governance networks, it is also a weakness because it may prevent networks from enhancing the efficiency and effectiveness, democratic legitimacy and innovative capacity 
of the public sector as a whole. The ultimate risk is that governance networks contribute to the balkanization of public governance in the sense that improvements in isolated parts of the public governance system fail to lead to more widespread improvements in the overall system, which suffers from fragmentation and stagnation as a result. In order to mitigate this inherent risk metagovernors must seek to apply a variety of metagovernance tools in order to maximize the impact of relatively sealed-off governance networks on their wider political and administrative environment.

Governance networks may enhance the efficiency and effectiveness of public governance in their immediate environment by contributing to the integration and alignment of policy solutions and public services across levels, sectors and silos. The problem-solving capacity of the public sector is often hampered by rather inflexible horizontal and vertical institutional divides, and governance networks may serve as vehicles for crosscutting and multi-level coordination. For instance, a governance network consisting of a high school director, local citizens, police and parole officers and managers from the local school district may succeed in helping a group of at-risk youth to stay in school and out of trouble by offering a more integrated and holistic service. However, the local solution achieved through multi-actor collaboration may have a wider impact on effective crime-prevention by serving as a starting point for the development of a city-wide strategy that builds on ideas from the local solution while broadening the agenda and the range of the actors involved in the network. In this way, collaborative governance can 'scale up' (Ansell and Torfing, 2015). For this to happen, metagovernors must contemplate how the attempt to solve a particular problem in an efficient and effective way would benefit from a widening of the political and administrative context for its solution and how the wider context may benefit from an extension of the principles and ideas that helped to produce an efficient and 
effective solution in the first place. In the attempt to improve public governance by expanding the context for solving problems and applying efficient and effective solutions, metagovernors may also consider whether the range of network actors should be broadened to include actors from adjacent policy sectors or other levels of government in order to create synergies through the alignment of goals and perceptions and coordination of action.

Governance networks may also strengthen the functioning of representative democracy that currently suffers from growing legitimacy problems. The increasing complexity of public governance makes it difficult for elected politicians to make well-informed political decisions, ensure broad ownership and oversee the implementation of policy and service solutions in complex and hybrid governance regimes (Christensen and Lægreid, 2011). Governance networks can assist elected politicians at different levels of government in making and implementing political decisions by providing relevant information, enhancing political support from relevant stakeholders and ensuring the crosscutting coordination and alignment of strategic actions with overall policy objectives. To make this happen, metagovernors must institutionalize mechanisms that facilitate communication between formal government and less formal governance arenas. It is particularly important that metagovernors succeed in creating institutional mechanisms that enable elected politicians to hold governance networks democratically to account in order to avoid mission creep. One way to do this is to actively involve elected politicians and government officials in the metagovernance of governance networks through political agenda setting, reviewing and perhaps even through (occasional) participation in governance networks (Sørensen and Torfing, 2005, 2016). Network participation will grant the participating politicians extensive knowledge about the complexities involved in governance domains such as water 
management or business development, which can prove valuable in future policy-making processes. Another way in which elected politicians can hold governance networks to account and thus use them to extend their reach when it comes to governing complex policy areas is to create a political and institutional framework for governance networks that grants them what Archon Fung calls 'accountable autonomy' (Fung, 2006). The formulation of overall goals and guidelines followed by regular reporting on how governance networks act and perform within the remit they have been given will help to ensure accountability and thus enable elected politicians to extend their democratic authority by acting in and through networks.

Finally, it is important that metagovernors urge innovative governance networks to diffuse their innovations to relevant public and private domains and actors outside the network. The production of public value may suffer if innovative policies and services and creative organizational and procedural designs developed in network settings and successfully implemented in a particular area are not diffused beyond the narrow confines of the network. In private markets, innovation diffusion is driven by competition and profit motives, but in governance networks and public agencies there are few incentives to diffuse innovations across networks and agencies, unless their comparative advantage is clearly demonstrated and the innovative solution is deemed compatible with the culture and values of the adopter's organization (Greenhalgh et al., 2004). As such, a key task for metagovernors is to encourage the network actors to become ambassadors for their networked innovations and spread the new ideas and practices by exploiting their strong and weak ties and creating new ones (Rogers, 1995). Research shows that face-to-face meetings that allow the communication of tacit knowledge about innovative solutions have a significant effect on innovation diffusion (Rashman and Hartley, 2002). Hence, it is not 
enough for metagovernors to create websites with best practices. They must also create real-life platforms for interpersonal dialogue with potential adopters.

\section{Metagovernance of networked innovation in elderly care in Denmark}

In order to illustrate how metagovernors can spur collaborative innovation in networks, we will now provide a brief empirical analysis of a successful case of networked innovation in Danish elderly care. The analysis is based on interviews with the project leaders and supplemented with document studies.

Today, the cocreated Danish elderly care project, 'Cycling without Age' (http://cyclingwithoutage.org/), is known all over the world as an innovative new way to improve the quality of life of elderly people. The project was initiated in 2010 by a Danish social entrepreneur who regularly cycled past a local nursing home in Copenhagen and observed the residents' limited mobility. He hired a rickshaw, drove over to the nursing home and offered to take the residents on a bike trip around town in exchange for hearing their life stories. The staff at the nursing home immediately welcomed the idea and helped to facilitate the first ten bike rides. The local initiative was an immense success, and together the social entrepreneur and the nursing home applied to the municipality for money to purchase a rickshaw in order to consolidate the local innovation. The public employee who processed the application was employed as a 'boundary spanner' whose task was to enhance collaboration with civil society actors. She contacted the social entrepreneur and told him that the municipality would purchase a number of rickshaws if he would help to establish a network of volunteers who could drive elderly people around Copenhagen in order to enhance their mobility and quality of life. The publicly employed 
boundary spanner and the social entrepreneur developed a close relationship and shared the responsibility for metagoverning the development of the collaborative innovation project that involved a handful of social entrepreneurs, a group of public and private sponsors, scores of local volunteers, social workers at the nursing homes in Copenhagen, and, of course, the elderly. In their capacity as metagovernors, they focused explicitly on enrolling the right type of actors into the network, promoting their capacity to develop and implement innovative ideas, and diffusing the innovative public services to other Danish municipalities and, later on, to the rest of the world.

The metagovernors assembled a small group of social entrepreneurs ('the managing team') to help them develop and refine the innovative solution and set up the basic infrastructure of the project, which included: local networks of voluntary rickshaw 'pilots' led by experienced 'captains'; a website with information about the project and instructional videos about how to drive elderly people around safely; an on-line booking system enabling pilots and elderly people, assisted by social workers, to make appointments for rides; and a start-up package complete with rickshaws, insurance for accidents, and informational and promotional material that enabled new nursing homes in Copenhagen and other municipalities to adopt the innovative practice of having volunteers give elderly people rickshaw rides. The two metagovernors made a deliberate effort to attract creative people with different skills and competences to the managing team, the network of supporters and an advisory board. They also sought to recruit people with lots of energy and good communication skills to the local networks of voluntary pilots and to identify potential adopters in other municipalities who were brought together in a national innovation network that focused on innovation diffusion. 
While some of the debates in the overlapping innovation networks focused on practical issues related to developing the infrastructure of the project in order to meet the growing demand for rickshaw rides, other discussions aimed to develop a new understanding of what elderly care is all about and how it is provided. The two metagovernors played a key role in facilitating these debates. The first result was the formulation of the slogan: 'Elderly people have the right to feel the wind in their hair', which is a metaphor for the right of elderly people to live a full life with geographical mobility, social events, and new experiences and friendships. The second result was that the role of volunteers in improving the quality of life of elderly people in nursing homes came to be seen as a novel way of providing public services and, ultimately, for a new way of thinking about the public sector. In this view, the public sector should neither be seen as an 'authority' vis-a-vis subordinate citizens nor as a 'service provider' to more or less satisfied customers. Instead, it should be perceived as an 'arena for co-creation', bringing public and private actors together in developing new and better services for the elderly as well as for other groups of citizens with particular needs. A number of concrete projects informed by this new way of thinking about the public sector are underway, and Cycling without Age is striving to convince the municipalities that adopt the new bicycle project that it is not just about providing an extra service to the elderly, but really about rethinking public service production altogether.

Finally, the metagovernors made a dedicated effort to diffuse the Cycling without Age project. First, they created a National Association for Cycling without Age, setting up local chapters and promoting the exchange of experiences and ideas. Next, they created a Global Association for Cycling without Age that aims to bring national associations together in a global network. Homepages, streamers, and mediatized events help to 
spread the word, and long-distance rickshaw trips with elderly people to major cities in neighboring countries were instrumental in demonstrating the power of the new idea. A well-received TED talk, the successful dissemination of videos on You Tube, and a global crowdfunding of rickshaws for cities in Asia and South America have diffused Cycling without Age all around the globe. Today, only five years after the first rickshaw was purchased by the Municipality of Copenhagen, Cycling without Age has spread to more than half of the Danish municipalities, and to 18 cities in 10 other countries. These achievements, which speak for themselves, would not have been possible if it had not been for the skillful metagovernance of the networked co-creation of public innovation.

\section{Conclusion}

Today, public authorities all over the Western world aim to heighten the efficiency, effectiveness and democratic legitimacy of public governance by enhancing innovation. While the first strategies for stimulating public innovation celebrated top-down entrepreneurial leadership and public-private competition, recent strategies inspired by the attempt to fuse innovation and governance theory tend to see collaboration between public and private actors as the ultimate driver of public innovation (Sørensen and Torfing, 2011). The new public innovation theories perceive the formation of governance networks as a promising strategy for promoting collaborative innovation. This article has aimed to show that efforts to promote networked innovation in the public sector call for a specific kind of metagovernance that deviates in important respects from metagovernance strategies aimed at enhancing effective and democratic governance through continuous improvement. An innovation-enhancing metagovernance strategy must explicitly seek to 
include actors with different backgrounds and perspectives who together possess the relevant innovation assets. It must also assist network actors in creative destruction by encouraging joint development and testing of new and bold solutions and supporting the diffusion of successful innovations to relevant audiences. In short, metagovernors of collaborative innovation in networks must harness diversity, create appropriate disturbance and recruit innovation ambassadors. Our analysis of the role of metagovernance in the highly successful innovation project, 'Cycling without Age', illustrates the importance of metagoverning governance networks in order to enhance their innovative capacity. However, comparative studies of how networked innovation is metagoverned are needed in order to expand and refine the toolbox of metagovernors and test the efficiency of different tools. Preferably, such studies should be embedded in a broader research program that explores the scope conditions for collaborative innovation in networked governance arenas, the contingent choice between different metagovernance tools and the viability of collaborative innovation as a strategy for improving public performance. Our hope is that the ideas set out in this article can inform the development of such a research program. 


\section{References}

Agger, A. and Sørensen, E. (2014), 'Designing collaborative policy innovation: Lessons from a Danish municipality', in Ansell, C. and Torfing, J. (Eds), Public Innovation through Collaboration and Design, New York: Routledge, pp. 188-208.

Agranoff, R. I. and McGuire, M. (2003), Collaborative Public Management: New Strategies for Local Government, Washington, DC: Georgetown University Press.

Ansell, C. and Gash, A. (2008), 'Collaborative governance in theory and practice', Journal of Public Administration Research and Theory, 18(4): 543-571.

Ansell, C. and Gash, A. (2012), 'Stewards, Mediators, and Catalysts: Towards a Model of Collaborative Leadership', Public Sector Innovation Journal, 17(1): 1-21.

Ansell, C. and Torfing, J. (Eds) (2014), Public Innovation through Collaboration and Design, New York: Routledge.

Ansell, C. and Torfing, J. (2015), 'How does collaborative governance scale?', Policy and Politics, 43(3): 315-329.

Bason, C. (2010), Leading Public Sector Innovation: Co-creating for a Better Society, Bristol: Policy Press.

Bland, T., Bruk, B., Kim, D. and Lee, K. T. (2010), 'Enhancing public sector innovation: Examining the network-innovation relationship', Public Sector Innovation Journal, 15(3): 125.

Bommert, B. (2010), 'Collaborative innovation in the public sector', International Public Management Review, 11(1): 15-33. 
Bozeman, B. (2007), Public Values and Public Interest: Counterbalancing Economic Individualism, Washington D.C.: Georgetown University Press.

Brown, L. and Osborne, S. (2013), 'Innovation and risk in public services: Towards a new theoretical framework', Public Management Review, 15(3): 186-208.

Cerny, P. C. (1997), 'Paradoxes of the Competition State: The Dynamics of Political Globalization', Government and Opposition, 32(2): 251-274.

Christensen, T. and Lægreid, P. (2011), 'Complexity and Hybrid Public Administration Theoretical and Empirical Challenges', Public Organization Review, 11(4): 407-423.

Considine, M., Lewis, J. and Alexander, D. (2009), Networks, Innovation and Public Policy, Basingstoke: Palgrave-Macmillan.

Dahl, R. (1989), Democracy and its Critics, New Haven: Yale University Press.

Dalton, R. (2004), Democratic Challenges, Democratic Choices: The Erosion in Political Support in Advanced Industrial Democracies, Oxford: Oxford University Press.

Dente, B., Bobbio, L. and Spada, A. (2005), 'Government or Governance of Urban Innovation?', DIPS, 162, 1-22.

Downs, A. (1975), Inside Bureaucracy, Boston: Little, Brown \& Company.

Dryzek, J. S. (2007), 'Networks and democratic ideals: Equality, freedom, and communication', in Sørensen, E. and Torfing. J. (Eds), Theories of Democratic Network Governance, Basingstoke: Palgrave-Macmillan, pp. 262-273. 
Edquist, C. (2005), 'Systems of innovation: Perspectives and challenges', in Fagerberg, J., Mowery, D. and Nelson, R. (Eds), Oxford Handbook of Innovation, Oxford: Oxford University Press, pp. 181-208.

Eggers, B. and Singh, S. (2009), The Public Innovators Playbook, Washington, DC: Harvard Kennedy School of Government.

EU Commission (2013), Powering European Public Sector Innovation: Towards a New Architecture, Brussels: EU Commission.

Faerman, S.R., McCaffrey, D.M. and Slyke, D.M. (2001), 'Understanding interorganizational cooperation: Public-private collaboration in regulating financial market innovation', Organizational Science, 12(3): 372-388.

Fung, A. (2006), Empowered Participation: Reinventing Urban Democracy, Princeton, NJ: Princeton University Press.

Freeman, C. (1991), 'Networks of innovators: A synthesis of research issues', Research Policy, 20(5): 499-514.

Gloor, P. A. (2005), Swarm Creativity: Competitive Advantage through Collaborative Innovation Networks, Oxford, Oxford University Press.

Gray, B. (1989), Collaborating: Finding Common Ground for Multiparty Problems, San Francisco: Jossey-Bass.

Greenhalgh, T., Robert, G., Macfarlane, F., Bate, P. and Kyriakidou, O. (2004), 'Diffusion of innovations in service organizations: Systematic review and recommendations', The Milbank Quarterly, 82(4): 581-629. 
Hartley, J. (2005), 'Innovation in governance and public service: Past and present', Public Money \& Management, 25(1): 27-34.

Hirst, P. (2000), 'Democracy and governance', in Pierre, J. (Ed.), Debating Governance, Oxford: Oxford University Press, pp. 13-36.

Hood, C. (1986), Tools of Government, London: Chatham House Publishers.

Hood, C. (1991), 'A public administration for all Seasons?', Public Administration, 69(1): 119.

Jessop, B. (1998), 'The rise of governance and the risk of failure: The Case of economic development', in UNESCO/155, Oxford: Blackwell Publishers.

Jessop, B. (2002), The Future of the Capitalist State, Cambridge: Polity Press.

Kickert, W. J. M., Klijn, E. H. and Koppenjan, J. (Eds) (1997), Managing Complex Networks, London: Sage.

Klijn, E. H. and Skelcher, C. (2007), 'Democracy and governance networks: Compatible or not?', Public Administration, 85(3): 587-608.

Kooiman, J. (Ed.) (1993), Modern Governance, London: Sage.

Kooiman, J. (2003), Governing as Governance, London: Sage.

Koppenjan, J. and Klijn, E. H. (2004), Managing Uncertainties in Networks, London: Routledge. 
Levin, K., Cashore, B., Bernstein, S., and Auld, G. (2012), 'Overcoming the tragedy of super wicked problems: constraining our future selves to ameliorate global climate change', Policy Sciences, 45(2): 124-152.

Lundvall, B. Å. (1985), Product Innovation and User-producer Interaction, Aalborg: Aalborg University Press.

Macmillan, P. and Cain, T. (2010), Closing the Gap: Eliminating the Disconnect between Policy Design and Execution, Washington, DC: Deloitte.

March, J. G. and Olsen, J. P. (1989), Rediscovering Institutions, New York, NY: The Free Press.

March, J. G. and Olsen, J. P. (1995), Democratic Governance, New York, NY: The Free Press.

Marsh, J. and Rhodes, R. A. W. (1992), Policy Networks in British Governance, Oxford: Oxford University Press.

Mazzucato, M. (2013), The Entrepreneurial State: Debunking Public vs. Private Sector Myths, London: Anthem Press.

McPherson, M., Smith-Lovin, L., and Cook, J. M (2001), 'Birds of a feather: Homophily in social networks', Annual Review of Sociology, 27(1): 415-444.

Milward, H. B. and Provan, K. G. (2006), A Manager's Guide to Choosing and Using Collaborative Networks, Washington, DC: IBM Endowment for Business of Government.

Milward, B.H. and Raab, J. (2007), 'Dark networks as organizational problem', International Public Management Journal, 9(3): 333-360. 
Norris, P. (2011), Democratic Deficit: Critical Citizens Revisited, New York: Cambridge University Press.

OECD (2015), Innovation Policies for Inclusive Growth, OECD Publishing, Paris.

DOI: http://dx.doi.org/10.1787/9789264229488-en

Osborne, S. (2010), The New Public Governance?, New York: Routledge.

Osborne, D. and Gaebler, T. (1993), Reinventing Government: How the Entrepreneurial Spirit is Transforming the Public Sector, Reading, MA: Addison-Wesley.

O'Toole, L. J. (1997), 'Implementing public innovations in network settings', Administration and Society, 29(2): 115-138.

Peters, B. G. (2010), 'Metagovernance and public management', in Osborne, S. (Ed.), The New Public Governance?, London: Routledge, pp. 36-51.

Pollitt, C. (2010), Public management reform during austerity: A Report to the Swedish Government, Stockholm: Statskontoret.

Porter, M. (1990), The Competitive Advantage of Nations, London: Macmillan.

Provan, K. G. and Kenis, P. N. (2008), 'Modes of network governance: Structure, management and effectiveness', Journal of Public Administration Research and Theory, 18(2): 229-52.

Rashman, L. and Hartley, J. (2002), 'Leading and learning? Knowledge transfer in the Beacon Council Scheme', Public Administration, 80(3): 523-542.

Rittel, H. J. W. and Webber, M. M. (1973), 'Dilemmas in the general theory of planning', Policy Science, 4(2): 155-169. 
Roberts, N. C. (2000), 'Wicked problems and network approaches to resolution', International Public Management Review, 1(1): 1-19.

Roberts, N. C. and King, P. J. (1996), Transforming Public Policy: Dynamics of Policy Entrepreneurship and Innovation, San Francisco, CA: Jossey-Bass.

Rogers, E. (1995), Diffusion of Innovations, New York: Free Press.

Sabatier, P. A. and Jenkins-Smith, H. C. (Eds) (1993), Policy Change and Learning, San Francisco, CA: Westview Press.

Scharpf, F. W. (1994), 'Games real actors play: Positive and negative coordination embedded negotiations', Journal of Theoretical Politics, 1(6): 27-53

Schumpeter, J. (1946), Economic Theory and Entrepreneurial History - Change and the Entrepreneur, Cambridge, MA: Harvard University Press.

Skelcher, C. and Torfing, J. (2010), 'Improving democratic governance through institutional design: Civic participation and democratic ownership in Europe', Regulation and Governance, 4(1): 71-91.

Smith, G. (2009), Democratic Innovation: Designing Institutions for Citizen Participation, Cambridge: Cambridge University Press.

Stoker, G. (2006), Why Politics Matters, Basingstoke: Palgrave Macmillan.

Sørensen, E. and Torfing, J. (2005), 'The democratic anchorage of governance networks', Scandinavian Political Studies, 28(3): 195-218.

Sørensen, E. and Torfing, J. (Eds) (2007), Theories of Democratic Network Governance, Basingstoke: Palgrave Macmillan. 
Sørensen, E. and Torfing, J. (2009), 'Making governance networks effective and democratic through metagovernance', Public Administration, 87(2): 234-258.

Sørensen, E. and Torfing, J. (2011), 'Enhancing collaborative innovation in the public sector', Administration and Society, 43(8): 842-868.

Sørensen, E. and Torfing, J. (2016), 'Political leadership in the age of interactive governance: Towards a theory of political metagovernance', in van Meerkerk, I. F. and Edelenbos, J. (Eds), Critical Reflections on Interactive Governance, Oxford: Oxford University Press, pp. ??

Sørensen, E. and Torfing, J. (forthcoming), 'The Janus face of governance and metagovernance theory: Depoliticizing or repoliticizing public governance', in Flinders, M., Hay, C. and Wood, M. (Eds), Anti-Politics, De-Politicization and Governance in Late Modernity, Oxford: Oxford University Press.

Teece, D. J. (1992), 'Competition, cooperation, and innovation', Journal of Economic Behaviour and Organization, 18(1): 1-25.

Theisman, G.; Burren, A.V. and Gerrits, L.M. (2009), Managing Complex Governance Systems, London: Routledge.

Torfing, J., Peters, B. G., Pierre, J. and Sørensen, E. (2012), Interactive Governance: Advancing the Paradigm, Oxford: Oxford University Press.

Torfing, J. (forthcoming), Collaborative Innovation in the Public Sector, Washington, DC: Georgetown University Press. 
Torfing, J., Sørensen, E. and Fotel, T. (2009), 'Democratic anchorage of infrastructural governance networks: The case of the Femern Belt Forum', Planning Theory, 8(3): 282-308. Warren, M. E. (2009), 'Governance-driven democratization', Critical Policy Studies, 3(1): 313.

Williams, P. (2002), 'The competent boundary spanner', Public Administration, 80(1): 103124.

Young, I. M. (2000), Inclusion and Democracy, Oxford: Oxford University Press. 
Figure 1: Causal links between governance networks and key performance goals

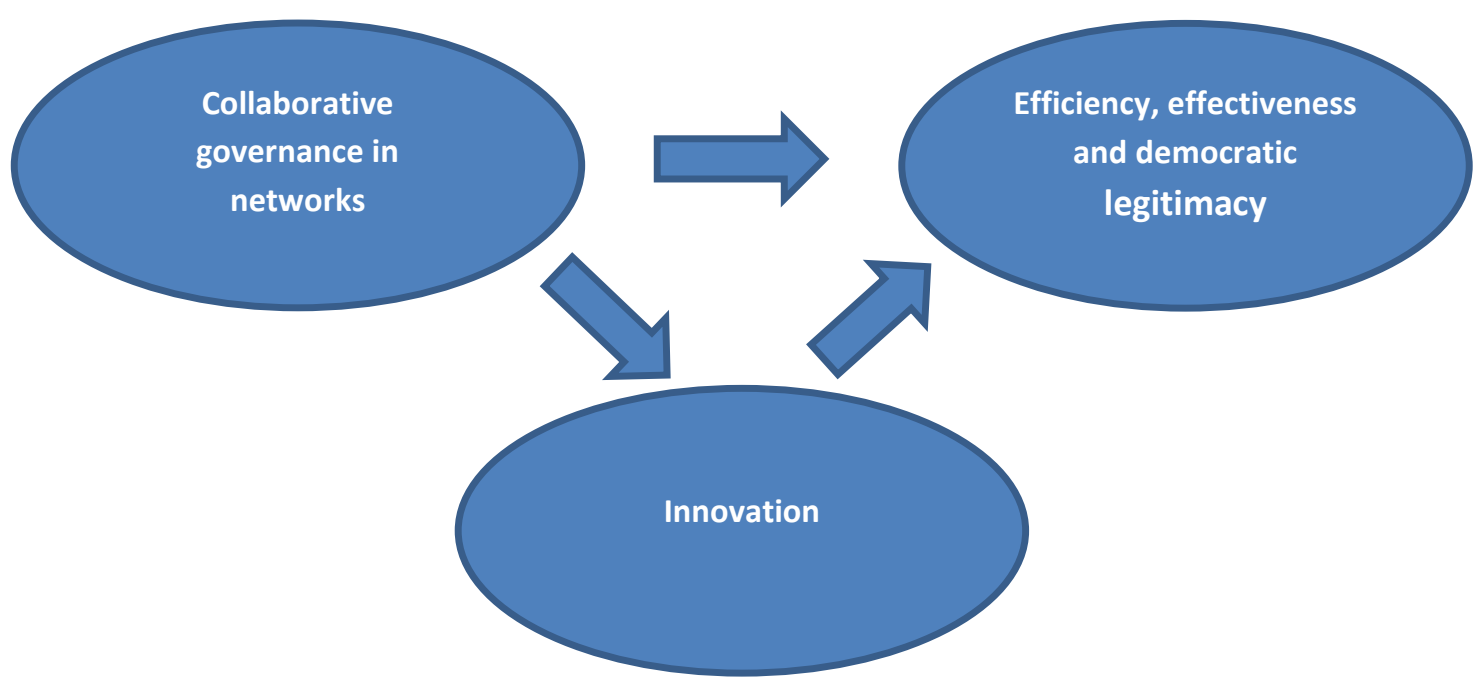


Table 1: $\quad$ Comparison of three metagovernance strategies

\begin{tabular}{|c|c|c|c|}
\hline $\begin{array}{l}\text { Purpose of } \\
\text { governance } \\
\text { networks? }\end{array}$ & $\begin{array}{l}\text { Enhance efficiency and } \\
\text { effectiveness through } \\
\text { continuous } \\
\text { improvement }\end{array}$ & $\begin{array}{l}\text { Enhance democratic } \\
\text { legitimacy through } \\
\text { continuous } \\
\text { improvement }\end{array}$ & $\begin{array}{l}\text { Promote innovation as a } \\
\text { tool for enhancing } \\
\text { efficiency, effectiveness } \\
\text { and democratic } \\
\text { legitimacy }\end{array}$ \\
\hline $\begin{array}{l}\text { Which actors } \\
\text { should be } \\
\text { included in the } \\
\text { governance } \\
\text { network? }\end{array}$ & $\begin{array}{l}\text { Actors with specialized } \\
\text { skills, competences, and } \\
\text { forms of knowledge, } \\
\text { complementary resources } \\
\text { and responsibilities, } \\
\text { commitment to common } \\
\text { goals and willingness to } \\
\text { manage their differences }\end{array}$ & $\begin{array}{l}\text { Intensely affected and } \\
\text { interested actors who } \\
\text { represent different } \\
\text { constituencies and views } \\
\text { and are empowered to } \\
\text { influence decisions that } \\
\text { affect their lives and } \\
\text { values }\end{array}$ & $\begin{array}{l}\text { A diverse set of committed } \\
\text { and open-minded actors } \\
\text { with different backgrounds } \\
\text { and different innovation } \\
\text { assets such as creativity, } \\
\text { ability to get things done } \\
\text { and inspire other actors to } \\
\text { adopt new solutions }\end{array}$ \\
\hline $\begin{array}{l}\text { What should the } \\
\text { network actors be } \\
\text { encouraged to do } \\
\text { in the network } \\
\text { arena? }\end{array}$ & $\begin{array}{l}\text { Exchange or pool their } \\
\text { resources in order to } \\
\text { clarify and solve a } \\
\text { particular governance } \\
\text { problem either through } \\
\text { negative or positive } \\
\text { coordination }\end{array}$ & $\begin{array}{l}\text { Aggregate and integrate } \\
\text { different views and } \\
\text { opinions in order to reach } \\
\text { joint decisions and seek } \\
\text { to mobilize support from } \\
\text { affected constituencies }\end{array}$ & $\begin{array}{l}\text { Engage in a creative } \\
\text { destruction of existing } \\
\text { beliefs and practices, } \\
\text { develop and test } \\
\text { prototypes of new and } \\
\text { promising ideas, and } \\
\text { communicate results }\end{array}$ \\
\hline $\begin{array}{l}\text { What kind of } \\
\text { impact should the } \\
\text { network have on } \\
\text { its external } \\
\text { environment? }\end{array}$ & $\begin{array}{l}\text { Integration and alignment } \\
\text { of policy solutions and } \\
\text { service provision across } \\
\text { silos and sectors }\end{array}$ & $\begin{array}{l}\text { Forge a link between } \\
\text { representative and } \\
\text { participatory democracy }\end{array}$ & $\begin{array}{l}\text { Diffuse promising ideas } \\
\text { and successful } \\
\text { innovations to a broad } \\
\text { variety of relevant } \\
\text { audiences }\end{array}$ \\
\hline
\end{tabular}

